\title{
Car Ownership of Households in Sub-Urban Area in Makassar City
}

\author{
Mubassirang Pasra ${ }^{1}$, Muhammad Isran Ramli ${ }^{1, *}$, and Dimas Endrayana Dharmowijoyo ${ }^{2}$ \\ ${ }^{1}$ Department of Civil Engineering, Faculty of Engineering, Universitas Hasanuddin, Indonesia \\ ${ }^{2}$ Department of Civil and Environmental Engineering, Universiti Teknologi Petronas, Malaysia
}

\begin{abstract}
The present study aims to grasp the car ownership characteristics of households in the sub-urban area in Makassar City, Indonesia. The study considers some exogenous characteristics of the households, such house types, family size, income, motorcycle ownership, trip number, and worker number. To construct the relationship between those characteristics and the car ownership, we applied the multinomial logit model approach. This study surveyed seven residential areas in the sub-urban area of the city. The survey conducted an interviewing method using a questionnaire sheet. The survey respondents as representative of the households, which selected randomly from the residential areas. The results show that the goodness of fit of the car ownership model is acceptable enough. Further, all of the exogenous variables significantly influence the households in car ownership. We expected that the results provide a basis for further studies such time valuation of car riders, mode choice model of the households, etc.
\end{abstract}

\section{INTRODUCTION}

In the last decade, the motor-vehicle ownership such car and motorcycle has increased rapidly in many cities in developing countries. For instance, the average annual growth rate approximately of the motorcycle is $11 \%$ in Bali, Indonesia [1], and $14 \%$ in Hanoi City, Vietnam [2].

The phenomenon leads to the road traffic problem such as traffic congestion increasing, traffic behavior changing from homogeneous to heterogeneous traffic, increasing of a traffic accident, etc. For example, regarding the traffic accident, motorcycle safety constitutes an increasingly significant in the cities. For example, motorcyclists contributed more than $60 \%$ of the road injuries on Malaysian roads [3]. In Thailand, $76 \%$ of the injured accident victims are either motorcycle drivers or passengers [4]. Especially in Indonesia, during 2003-2007 there were $70 \%$ of road accidents involved with motorcycles in Bali $[1,5]$.

\footnotetext{
Corresponding author: isranramli@unhas.ac.id
} 
Essensially addressed to find a solution for the high growth auto-car, firstly we have to more attention to the car ownership. However, only a few previous studies have focused on this matter for Asian developing countries. For instance, Verma et al. [6] have studied car ownership behavior for urban young adults in India. Also, Luke [7] spent attention for car ownership of student in South Africa. For Indonesia case, Susantono et al. [8] have studied the the car ownership which related to trip pattern for Jabodetabek Area, as well as, Senbil et al. [9] have studied the motorcycle ownership and use in Jabotabek (Indonesia) Metropolitan. Putranto et al. [10] have explored characteristics of the private car and motorcycle ownership using aggregate data (1990-2000) by the quasi-logistic model. Also, Asri et al. [11] have focused on motorcycle ownership of households in Makassar City.

In contributing to the research field, the present paper attempts to grasp the car ownership of households in Makassar City, Indonesia. In this regard, this study applies the multinomial logit (MNL) model approach in constructing the relationship between the car ownership and some household characteristics. The rest of this paper is presented as follows. The next section presents the methodology, then result in presentations. Finally, the paper provides a discussion and conclusion.

\section{THE STUDY METHODS}

\subsection{Multinomial Logit (MNL) Model Construction on the Car Ownership}

The multinomial logit model is one of the models approaches to represent the relationship between endogenous (dependent) variable (Y) that categorical and one or more exogenous variables $(\mathrm{X})$ that categorical and or continual. The multinomial logit model could be applied, when the endogenous variable consists of more than two categories.

The model has the assumption that the categories of the dependent variable result in $\mathrm{Y}$ follow the Bernoulli distribution. The probability function of the Y with the parameter $\square$ is stated as below:

$$
P(Y=y)=\gamma^{y}(1-\gamma)^{1-y}
$$

Where $\mathrm{y}=0,1$. Then, probabilities of each categories are $\mathrm{P}(\mathrm{Y}=1)=\square$ and $\mathrm{P}(\mathrm{Y}=0)=1-\square$ with $\mathrm{E}(\mathrm{y})=\square$, for $0 \leq \square \leq 1$.

The probability of the logistic regression that deals with $n$ exogenous variables could be formulated as follows $[12,13]$ :

$$
P(y \mid x)=\frac{e^{-\left(\beta_{0}+\beta_{1} x_{1}+\beta_{2} x_{2}+\ldots+\beta_{n} x_{n}\right)}}{1+e^{-\left(\beta_{0}+\beta_{1} x_{1}+\beta_{2} x_{2}+\ldots+\beta_{n} x_{n}\right)}}
$$

Where, $\mathrm{Xn}$ is the exogeneous variables which have the relevant attributes to the endogeneous variable, $\mathrm{Y}$, while $\square \mathrm{n}$ is the parameter of $\mathrm{Xn}$ have to estimate, and $\square 0$ is the specific constant of the model.

Regarding the above MNL model conception, this study constructs the MNL model to grasp the relationships between the car ownership as response variable (Y) and some identifying characteristics of households as exogenous variables (X). The following subsection will explain the specification of each variable that taking account into the MNL model. 


\subsection{Variable specification}

Table 1 shows the attributes or attitudes and types of the model variables that taking account in this study. The table shows that the endogenous variable (car ownership of households) consists of four car ownership categories, i.e., 0, 1, 2, and $>2$ units. Further, the exogenous variables that considered in this study include house type, family size, income, motorcycle ownership, worker number, and trip number.

Table 1. Variables and their attitude

\begin{tabular}{|c|c|c|}
\hline Variables & Symbols & Attributes/Attitudes of the Variables \\
\hline $\begin{array}{l}\text { 1. Car Ownership } \\
\text { (Unit) }\end{array}$ & $Y$ & $\begin{array}{llll}\text { a. } 0 & \text { b. } 1 & \text { c. } 2 & \text { d. } 3\end{array}$ \\
\hline 2. House Type $\left(\mathrm{m}^{2}\right)$ & $X_{H T}$ & $\begin{array}{lll}\text { a. } \leq 40 & \text { b. } 40-50 & \text { c. } 50-60 \\
\text { d. } 60-70 & \text { e. } 70-100 & \text { f. } 100-150 \text { g. } \\
>150 & & \\
\end{array}$ \\
\hline $\begin{array}{l}\text { 3. Family Size } \\
\text { (Person) }\end{array}$ & $X_{F Z}$ & $\begin{array}{llll}\text { a. } \leq 2 & \text { b. } 3-4 & \text { c. } 5-6 & \text { d. } 7-8 \\
\text { e. }>8 & & & \\
\end{array}$ \\
\hline $\begin{array}{l}\text { 4. Income (IDR } \\
\left.1 \times 10^{6}\right)\end{array}$ & $X_{\text {Inc }}$ & $\begin{array}{lll}\text { a. } \leq 0.5 & \text { b. } 0.5-1.0 & \text { c. } 1.0-1.5 \\
\text { d. } 1.5-2.0 & \text { e. }>2.0 & \\
\end{array}$ \\
\hline $\begin{array}{l}\text { 5. Motorcycle } \\
\text { Ownership (Unit) }\end{array}$ & $X_{M C O}$ & $\begin{array}{lll}\text { a. } 0 & \text { b. } 1 & \text { c. } 2\end{array}$ \\
\hline $\begin{array}{l}\text { 6. Worker Number } \\
\text { (Person) }\end{array}$ & $X_{W N}$ & $\begin{array}{lll}\text { a. } 0 & \text { b. } 1 & \text { c. } 2 \\
\text { e. }>3 & & \\
\end{array}$ \\
\hline $\begin{array}{l}\text { 7. Trip Number } \\
\text { (Time/Day) }\end{array}$ & $X_{T N}$ & $\begin{array}{ll}\text { b. } 1 & \text { c. } 2\end{array}$ \\
\hline
\end{tabular}

\subsection{Parameters estimation of the MNL model}

This study adopts the maximum likelihood theory in estimating the parameter values of the MNL model. The procedure to estimate maximum likelihood value involves the development of a joint probability density function of the observed sample, called the likelihood function, through estimation of parameter values which maximize the likelihood function. The likelihood function in case of $\mathrm{T}$ observation face $\mathrm{j}$ categories results is defined as follows [14]:

$$
L(\beta)=\prod_{\forall_{t} \in_{T}} \prod_{\forall_{j} \in_{j}}\left(P_{j t}(\beta)\right)^{\delta_{j t}}
$$

Where $\square \mathrm{jt}$ is chose indicator (=1 if $\mathrm{j}$ is occurred by observation $\mathrm{t}$ and 0 , otherwise) and Pjt is the probability when the observation $t$ gives event $\mathrm{j}$. The solution to maximize the loglikelihood function is the second derivation of the function. In this study, the parameters values of the model are estimated by using statistical package software, i.e., STATA 12.0.

\subsection{Data Collection}

This study collected data from seven residential areas in the northern part of Makassar City, Indonesia. The data collection purposed to grasp the household characteristics in the residential areas. The survey implemented an interviewing method using a questionnaire sheet which involves questions about the household characteristics, such as house types, car and motorcycle ownership, family size, the trip number in a day, worker number of family 
member, and income of households. In the survey, there were 686 respondents as representative of the households $( \pm 10 \%-30 \%$ of the population), which selected randomly from the residential areas. Table 2 shows the characteristics of the residential areas such as name, location, house number and sample size in this survey.

Table 2. Characteristics of the residential areas

\begin{tabular}{|c|c|c|c|c|}
\hline The Residential Areas & District & $\begin{array}{c}\text { Width } \\
\text { Area (Ha) }\end{array}$ & $\begin{array}{c}\text { House } \\
\text { Number } \\
\text { (Units) }\end{array}$ & $\begin{array}{c}\text { Number of } \\
\text { Samples } \\
\text { (Households) }\end{array}$ \\
\hline 1. Bukit Baruga (BB) & Tello & 50.0 & 750 & 200 \\
\hline 2. Bukit Khatulistiwa (BK) & Biringkanaya & 10.0 & 425 & 116 \\
\hline $\begin{array}{l}\text { 3. Citra Sudiang Indah } \\
\text { (CSI) }\end{array}$ & Biringkanaya & 50.0 & 900 & 92 \\
\hline $\begin{array}{l}\text { 4. Griya Mulya Asri } \\
\text { (GMA) }\end{array}$ & Biringkanaya & 3.4 & 175 & 36 \\
\hline $\begin{array}{l}\text { 5. Nusa Tamalanrea Indah } \\
\text { (NTI) }\end{array}$ & Tamalanrea & 25.0 & 1055 & 110 \\
\hline $\begin{array}{l}\text { 6. Sudiang Nusa Indah } \\
\text { (SNI) }\end{array}$ & Biringkanaya & 5.0 & 98 & 11 \\
\hline 7. Telkomas & Tamalanrea & 10.0 & 315 & 121 \\
\hline
\end{tabular}

\section{RESULTS AND DISCUSSION}

\subsection{Data Description}

Table 3 shows the summary description of the survey data, such mean, standard deviation, skewness, and kurtosis of each the household characteristic. In further, Figure 1 shows the characteristic of car ownership which related to each household characteristic.

Table 3. Statistical descriptions of the household characteristics

\begin{tabular}{|l|c|r|r|}
\hline \multicolumn{1}{|c|}{ Household Characteristics } & Symbols & Mean & Std. Deviation \\
\hline 1. Car Ownership (Unit) & $Y$ & 0.8455 & 0.7166 \\
\hline 2. House Type (m $\left.{ }^{2}\right)$ & $X_{H T}$ & 69.4723 & 35.96724 \\
\hline 3. Family Size (Person) & $X_{F Z}$ & 5.0175 & 1.6451 \\
\hline 4. Income (IDR $\left.1 \times 10^{6}\right)$ & $X_{I n c}$ & 1.7590 & 0.5104 \\
\hline 5. Motorcycle Ownership (Unit) & $X_{M C O}$ & 1.0423 & 0.7464 \\
\hline 6. Worker Number (Person) & $X_{W N}$ & 1.5350 & 0.7175 \\
\hline 7. Trip Number (Time/Day) & $X_{T N}$ & 1.1137 & 1.0975 \\
\hline
\end{tabular}

Table 3 indicates that all of the household characteristics as the exogenous variables have a pattern in following the normal distribution. Therefore, we include all of those variables in calculating of the multinomial logit model for the car ownership model.

Figure 1a shows that mostly the households have at least one-unit car for each various type of the households. However, for the house type less than $40 \mathrm{~m} 2$, mostly the household did not have a car. In the other side, the households which their house type more than $70 \mathrm{~m} 2$, 
dominated car ownership for one until two cars. The phenomena of the car ownership are mostly similar when the car ownership is correspondence to income and worker number of the household as shown in Figure 1c, and Figure 1e. For income categories, the households which have income more than 1.5 million rupiahs, have one until two-unit cars, as well as, the households which have equal or more than two worker number categories. Regarding the family size and the trip number characteristics of the households, Figure $1 \mathrm{~b}$ and Figure $1 \mathrm{f}$ show that here is no different proportion among categories of the family size and trip number when related to the car ownership. Also, Figure 1d describes the relationship phenomena between the car ownership and the motorcycle ownership of the household. In this regard, the more the household have a motorcycle, the more the households do not have cars. However, the households having more than two motorcycles are dominant having two units cars or more.

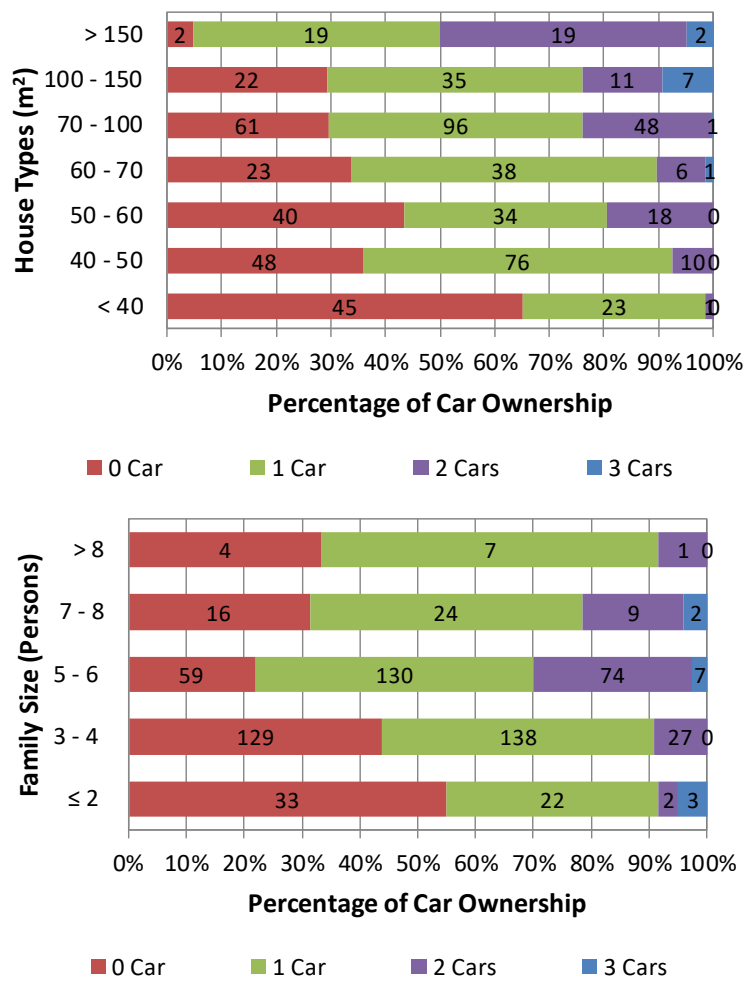
a. House Types vs. Car Ownership
b. Family Size vs. Car Ownership 


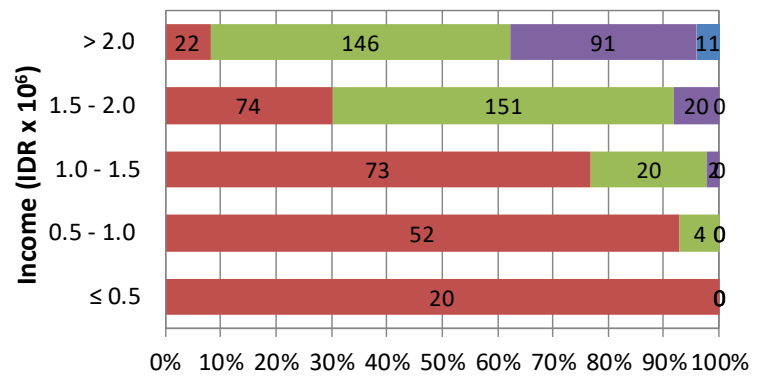

Percentage of Car Ownership

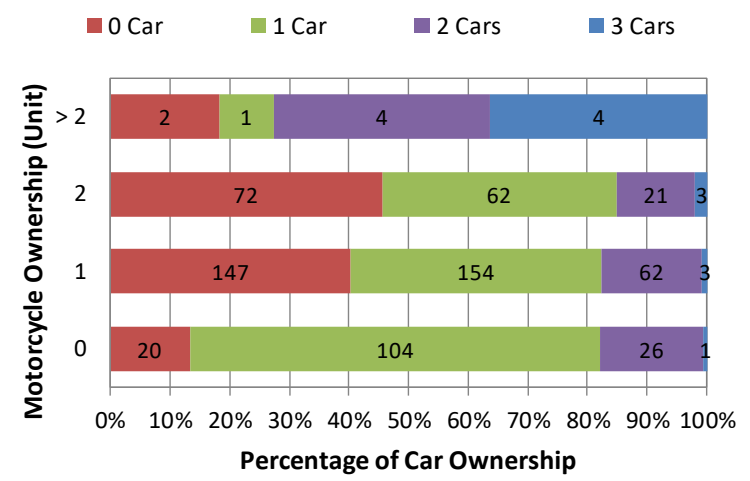

- 0 Car $\quad$ Car $\quad$ Cars

c. Income vs. Car Ownership d. Motorcycle Ownership vs. Car Ownership 

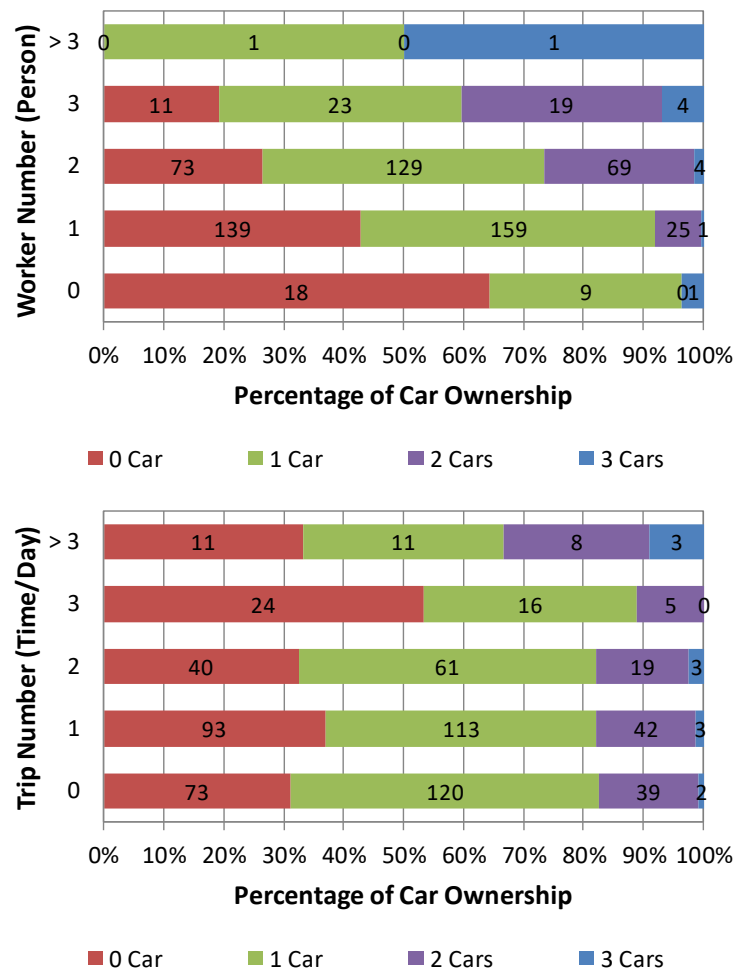

e. Worker Number vs. Car Ownership f. Trip Number vs. Car Ownership

Fig.1. The Relationship Among Car Ownerships, and Characteristics of the Households

\subsection{Model Estimation Result}

Calibration and validation of the MNL model in estimating and assessing the parameters values of the car ownership model utilized statistical method approach. There were two kinds of statistical test which adopted, i.e., significant test (i.e., $p$ value) to evaluate the contribution of each variable itself to the model, and the goodness of fit statistic test to validate the goodness of fit of the model. Table 4 presents the parameters values and statistical indicators of the model.

Table 4 shows that the car ownership model has enough acceptable level overall statistical fit indicator. The Likelihood ratio or pseudo- $\square 2$ indicators provided values 0.5141 . Regarding Ramli et al., [12], and Asri et al., [13], the values indicate that the model is acceptable in enough significant level. In providing additional insight, Table 3 also shows the hit ratio value, correct percentage between observed data and predicted model, more than $50 \%$ that indicated the model is acceptable to describe the relationship between motorcycle ownership variable and the household characteristics variables.

Furthermore, Table 4 shows that all variables of the model have significantly influenced the car ownership of the households for the categories the households have a one-unit car and two-unit cars. However, all the variable influences ignored for the household have more than two-unit cars category. The ineffectiveness of the household income level on the car ownership due to the car purchasing agent proposes a very easy system for buying a car, nowadays. 
Table 4. Calculation results of the model's parameters values

\begin{tabular}{|c|c|c|c|c|c|c|c|c|c|c|}
\hline \multirow{3}{*}{$\begin{array}{c}\text { Variable } \\
\mathrm{s}\end{array}$} & \multirow{3}{*}{$\begin{array}{c}\text { Para } \\
- \\
\text { met } \\
\text { ers }\end{array}$} & \multicolumn{9}{|c|}{ Parameter values of utility functions of each car ownership category } \\
\hline & & \multicolumn{3}{|c|}{ 1 Unit Car } & \multicolumn{3}{|c|}{2 Units Cars } & \multicolumn{3}{|c|}{$>2$ Units Cars } \\
\hline & & B & $\begin{array}{l}\text { Std. } \\
\text { Err. }\end{array}$ & $\begin{array}{c}\mathrm{P}>[ \\
\mathrm{z}]\end{array}$ & B & $\begin{array}{l}\text { Std. } \\
\text { Err. }\end{array}$ & $\begin{array}{l}\mathrm{P}> \\
{[\mathrm{z}]}\end{array}$ & B & $\begin{array}{l}\text { Std. } \\
\text { Err. }\end{array}$ & $\begin{array}{c}\mathrm{P}>[ \\
\mathrm{z}]\end{array}$ \\
\hline HouseT & $\beta_{X H}$ & 0.01 & & 0.00 & 0.022 & & 0.0 & & & 0.99 \\
\hline ypes & $T$ & 16 & 0.004 & 3 & 9 & 0.006 & 00 & 0.0604 & 41.632 & 9 \\
\hline FamilyS & $\beta X_{F}$ & 0.44 & & 0.00 & 0.155 & & 0.2 & & 429.86 & 0.99 \\
\hline ize & $z$ & 80 & 0.086 & 0 & 7 & 0.122 & 00 & 0.3904 & 8 & 9 \\
\hline & $\beta X_{I n}$ & 3.87 & & 0.00 & 5.944 & & 0.0 & 49.520 & 2308.7 & 0.98 \\
\hline Income & ${ }^{c}$ & $\begin{array}{r}36 \\
-\end{array}$ & 0.417 & 0 & $\begin{array}{l}1 \\
-\end{array}$ & 0.885 & 00 & 5 & 42 & 3 \\
\hline & $\beta X_{M}$ & 0.98 & & 0.00 & 1.262 & & 0.0 & - & 1001.5 & 0.99 \\
\hline MCOwn & CO & 82 & 0.178 & 0 & 2 & 0.292 & 00 & 1.8309 & 01 & 9 \\
\hline Family & $\beta X_{W}$ & 0.59 & & 0.00 & 1.140 & & 0.0 & & 1174.2 & 1.00 \\
\hline Work & N & 10 & 0.209 & 5 & 8 & 0.341 & 01 & 0.5316 & 71 & 0 \\
\hline & $\begin{array}{c}\beta X_{T} \\
N\end{array}$ & 0.26 & & 0.02 & 0.439 & & 0.0 & - & 652.22 & 0.99 \\
\hline NoTrip & ${ }^{N}$ & 92 & 0.117 & 2 & $\begin{array}{l}4 \\
-\end{array}$ & 0.192 & 22 & $\begin{array}{r}0.6903 \\
-\end{array}$ & 3 & 9 \\
\hline & $\beta_{o}$ & 3.52 & & 0.00 & 11.94 & & 0.0 & 127.15 & 6919.6 & 0.98 \\
\hline Constant & & 98 & 0.624 & 0 & 81 & 1.752 & 00 & 84 & 13 & 5 \\
\hline Number & obser & & & & & & & & & 658 \\
\hline Likelihoo & ratio, & & & & & & & & & .5141 \\
\hline
\end{tabular}

Note ${ }^{1}$ Significant at $95 \%$; The reference category is the car ownership $=0$

\section{CONCLUSSION}

The influenced of household characteristics such house type, family size, income, motorcycle ownership, number of worked family member, and trip number in a day, on the car ownership of the households in the sub-urban area have been explored in this paper. Through utilization of multinomial logit (MNL) model approach, the relationship between the exogenous and the endogenous variables has been evaluated and assessed in case the car ownership of the residential households in Makassar, Indonesia.

The household characteristics such house types, family size, income, motorcycle ownership, number of worked family member, and trip number in a day, have become the variables which influenced the car ownership of the households. Finally, the results may lead to the influence on the time valuation of the drivers and travel mode choice of the households, two subjects for continuous studies of this paper in further.

\section{REFERENCES}

1. D.M.P. Wedagama, and D. Dissanayake. Analysing Motorcycle Injuries on Arterial Roads in Bali Using Multinomial Logit Model. Journal of the Eastern Asia Society for Transportation Studies,8, pp. 1892-1904. (2010) 
2. V. A. Tuan, and T. Shimizu, Modeling of Household Motorcycle Ownership Behavior in Hanoy City. Journal of the Eastern Asia Society for Transportation Studies ,6, pp. 1751-1765. (2005)

3. U.R.S. Radin, G.M. Murray, and L.H. Brian, Preliminary Analysis on Impact of Motorcycle Lanes Along Federal Highway F02, Shah Alam, Malaysia. Journal of IATSS Research ,19(2) 12 -17. (1995)

4. M. Hossain , P. Iamtrakul. Medical Investigation of Motorcycle Accident in Thailand. Journal of the Eastern Asia Society for Transportation Studies, 7, pp. 2770-2785. (2007)

5. D.M.P. Wedagama, and D. Dissanayake.The Influence of Accident Related Factors on Road Fatalities Considering Bali Province in Indonesia as a Case Study. Journal of the Eastern Asia Society for Transportation Studies,8, pp. 1905-1917. (2010)

6. M. Verma, M. Manoj, A. Verma. Analysis of the influences of attitudinal factors on car ownership decisions among urban young adults in developing country like India. Transportation Research Part F: Traffic Psychology and Behaviour,42(1) pp. 90-103. (2016)

7. Rose Luke, Car ownership perceptions and intentions amongst South African students. Journal of Transport Geography,66, pp. 135-143. (2018).

8. B. Susantono, W. Santoso, A. Budiyono. Kepemilikan Kendaraan dan Pola Perjalanan di Wilayah JABODETABEK. Jurnal Transportasi,11, pp. 153-162. (2011)

9. M. Senbil, J. Zhang, and A. Fujiwara. Motorcycle Ownership and Use in Jabotabek (Indonesia) Metropolitan Area. Discussion Paper Series. 2006-3, Graduate School of International Development and Cooperation, Hiroshima Univeristy, Japan. (2006)

10. Putranto, Grant-Muller dan Montgomery. Characteristics of Private Car and Motorcycle Ownership in Indonesia, Proceeding of the Eastern Asia Society for Transportation Studies,6, (2007).

11. A. Asri, M. I. Ramli, L. Samang, 2012. A Study on Motorcycle Ownership of Residential Households in Makassar. Proceeding of The $15^{\text {th }}$ FSTPT International Symposium, STTD Bekasi, November 23-24, (2012).

12. M.I. Ramli, Y. Oeda, and T. Sumi, Study on Choice Model of Trip for Daily Household Logistic based on Binomial Logit Model. Proceeding of the 3rd Conference of Transportation and Logistic. (2010)

13. A. Asri, M. I. Ramli, L. Samang, 2011. Motorcyclist Acceptability on Road Safety Policy: Motorcycle Exclusive Lane in Makassar. Proceeding of the 15th FSTPT International Symposium, Pekanbaru, November 11-13, (2011).

14. F.S. Koppelman, and C. Bhat. A Self Instructing Course in Mode Choice Modeling: Multinomial and Nested Logit Model. U.S. Department of Transportation Federal Transit Administration. (2006) 